\title{
Nurmikasvien koostumus, pepsiini-HCl-liukoisuus ja in vitro-sulavuus eri kasvuasteilla
}

\author{
Maija-Liisa Salo, Anneli Nykänen ja Rittta Sormunen \\ Yliopiston kotieläintieteen laitos, Helsinki
}

\section{Composition, pepsin- $\mathrm{HCl}$ solubility and in vitro digestibility of forages at different growth stages}

\author{
Maija-Litsa Salo, Anneli Nykänen and Rittta Sormunen \\ Department of Animal Husbandry, University of Helsinki.
}

\begin{abstract}
The composition of meadow fescue and timothy was determined weekly during the first crop growth in two years and that of triploid red clover and couchgrass in one year. The purpose was primarily to study at what growth stage these forages should be harvested for green meal, suitable to pigs and poultry.

The recommended stage for harvesting is when the crop is $25-35 \mathrm{~cm}$ high $(2-3$ leaf stage) or $1 \frac{1}{2}-2$ weeks before ear emergence. At this stage the crude protein content of grasses was, in the favourable spring, $24-28 \%$, and in the unfavourable spring, $16-21 \%$ of dry matter. The pepsin solubility of protein was $80-85 \%$ and the crude fibre content was below $20 \%$. Pepsin- $\mathrm{HCl}$ soluble organic matter was $50-53 \%$ and in vitro soluble organic matter $80-82 \%$ of dry matter. The quality of timothy deteriorated fastest and that of couch-grass slowest. The quality of red clover deteriorated much slower than that of the grasses; even three weeks after the meadow fescue was harvested the clover was still comparable to this in quality.

In the unfavourable spring, the crude protein content of leaf stage grasses was $6-8$ $\%$-units lower, that of water soluble carbohydrates was as much higher, and the ash content about $2 \%$-units lower than in the favourable spring.

During the most intensive growth the $\mathrm{K}$-, Fe-, Mn- and $\mathrm{Zn}$-contents of forages decreased sharply, and the P- and Ca-contents decreased slightly. The $\mathrm{Mg}-, \mathrm{Na}-$ and $\mathrm{Cu}$-contents were fairly constant during the whole growth period.
\end{abstract}

Yleisesti tunnettu asia on että nurmikasvien koostumus muuttuu kehitysasteen mukaan siten, että kasvit tulevat rehuna yhä vähäarvoisemmiksi. Kehityskulkua on paljon tutkittu etenkin sopivan säilörehun ja heinän korjuuajankohdan määrittämiseksi (esim. Номв 1953, KıviмäE 1959, 1965, FulkerSOn ym. 1967, Poutiainen ja Rinne 1971, SyrJälä 1973). Tällä tutkimuksella pyrittiin ensi sijaisesti selvittelemään, millä kehitysasteella nurminadan, timotein ja triploidi puna-apilan ensimmäinen sato pitäisi korjata, jotta niistä saa- 
taisiin yksimahaisille sopivaa viherjauhoa, mutta silti kohtuullinen hehtaarisato. Kriteeriona pidettiin lähinnä raakaproteiinin, pepsiiniliukoisen proteiinin ja pepsiini-HCl-liukoisen orgaanisen aineen pitoisuutta. Ensimmäisenä vuonna kasvien kehitystä seurattiin niin pitkälle että saatiin tietoa myös siitä, missä kehitysvaiheessa kasvit olisi edullista korjata säilörehuksi ja heinäksi.

\section{Kokeen järjestely}

Koekasveina olivat Tammiston nurminata ja timotei sekä Viikin triploidi puna-apila. Nurminata kasvoi vuonna 1973 toisen vuoden laidunnurmessa, timotei toisen vuoden ja puna-apila ensimmäisen vuoden niittonurmessa. Vuonna 1974 tutkittiin samoilla peltolohkoilla kasvavaa nataa ja timoteitä ja lisäksi nadan joukossa kasvavaa juolavehnää.

Kevätlannoituksena annettiin vuonna 1973 nurminadalle $500 \mathrm{~kg} / \mathrm{ha}$ normaalia Super-Y-lannosta $(15 \% \mathrm{~N})$, timoteille $400 \mathrm{~kg} / \mathrm{ha}$ booripitoista SuperY:tä $(10 \% \mathrm{~N})$ ja puna-apilalle samaa $300 \mathrm{~kg} / \mathrm{ha}$. Vuonna 1974 nurminata sai jälleen $500 \mathrm{~kg} / \mathrm{ha}$ Super-Y:tä ja timotei $400 \mathrm{~kg} / \mathrm{ha}$ tasaväkevää Super-Y:tä $(15 \% \mathrm{~N})$.

Koeajan keskilämpötilat ja sademäärät kymmenpäivän jaksoina sekä vastaavat pitkäaikaiset keskiarvot esitetään taulukossa 1 .

Taulukko 1. Säätietoja koeajalta.

Table 1. Meteorological data on the experimental periods.

\begin{tabular}{|c|c|c|c|c|c|c|}
\hline & \multicolumn{3}{|c|}{ Lämpötila - Temperature, ${ }^{\circ} \mathrm{C}$} & \multicolumn{3}{|c|}{ Sademäärä - Rainfall, mm } \\
\hline & 1973 & 1974 & $1881-1970$ & 1973 & 1974 & $1881-1970$ \\
\hline 1. $-30.4, \ldots \ldots \ldots \ldots \ldots \ldots \ldots \ldots \ldots \ldots$ & 2.8 & 2.7 & 2.3 & 69 & 13 & 40 \\
\hline 1. $-10.5 . \quad \ldots \ldots \ldots \ldots \ldots \ldots \ldots$ & 7.5 & 4.9 & 6.5 & 5 & 15 & 12 \\
\hline 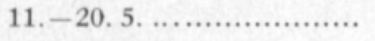 & 8.6 & 8.9 & 8.7 & 27 & 0 & 13 \\
\hline 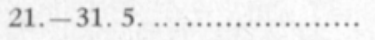 & $11.3 \quad 3.4$ & 7.9 & 10.8 & 0 & 21 & 14 \\
\hline 1. $-10.6 . \ldots \ldots \ldots \ldots \ldots \ldots \ldots \ldots$ & 17.37 .3 & 10.0 & 12.9 & 14 & 18 & 13 \\
\hline 11. $-20.6 \ldots \ldots \ldots \ldots \ldots \ldots \ldots$ & $13.2-3=$ & 16.9 & 14.5 & 3 & 9 & 15 \\
\hline $21 .-30.6 \ldots \ldots \ldots \cdots \cdots \cdots \cdots \cdots \cdots$ & 20.3 & - & 15.6 & 8 & - & 18 \\
\hline 1. $-10.7, \ldots \ldots \ldots \ldots \ldots \ldots \ldots$ & 22.0 & - & 16.3 & 0 & - & 22 \\
\hline
\end{tabular}

Näytteet otettiin varhaiselta lehtiasteelta lähtien viikon (1973) tai 3-7 päivän välein (1974) noin klo 13. Ruoho leikattiin $3-5 \mathrm{~cm}$ :n korkeudelta noin 10 eri kohdasta peltolohkoa. Laboratoriossa eroteltiin pois vieraat kasvilajit ja mahdollinen sänki, näyte silputtiin ja kuivattiin kuiva-ainenäyte kuivauskaapissa $100-105^{\circ} \mathrm{C}$ :ssä ja analyysinäyte vakuumissa $40-50^{\circ} \mathrm{C}$ :ssa. Osasta näytteitä määritettiin erilaisia kasvien morfologista kehitysastetta kuvaavia seikkoja (taulukko 2).

Virallisen rehuanalyysin määritykset suoritettiin standardimenetelmillä, vesiliukoiset hiilihydraatit SALOn (1965) menetelmällä. Pepsiini-HCl-liukoinen raakaproteiini ja orgaaninen aine määritettiin seuraavasti: 1 g näytettä 
Taulukko 2. Kehitysastetta kuvaavia lukuja.

Table 2. Data about the growth stage of herbages.

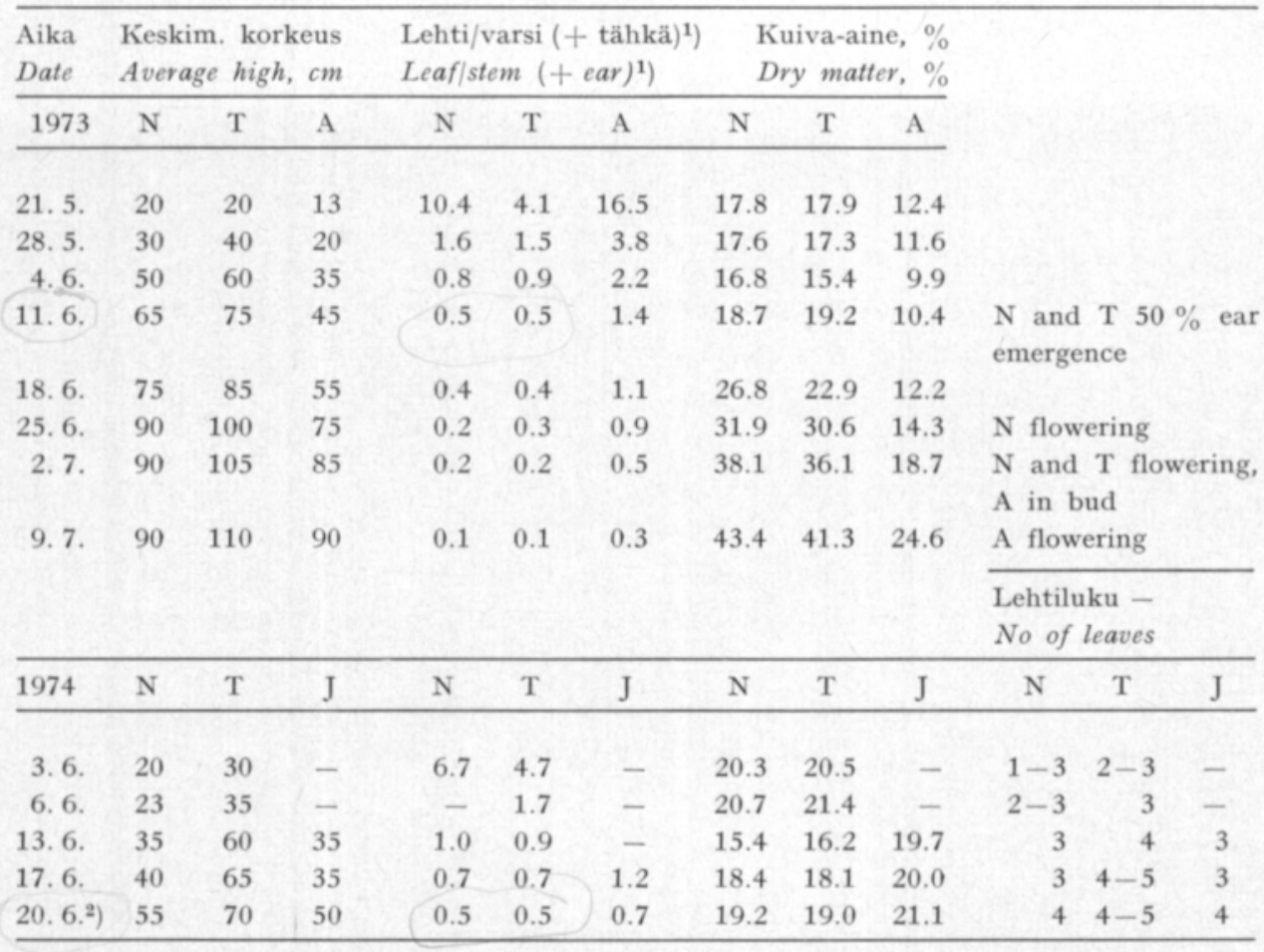

$\mathrm{N}=$ nurminata - meadow fescue $\mathrm{T}=$ timotei - timothy $\mathrm{A}=$ puna-apila - red clover $\mathrm{J}=$ juolavehnä - couch-grass

1) k.a. suhde - dry matter ratio.

$\left.{ }^{2}\right)$ N ja T: $20 \%$ tullut tähkälle 20,6.1974-N and T:20\% ear emergence on June 20, 1974.

pantiin $100 \mathrm{ml}: \mathrm{n}$ erlenmeyerpulloon. Pullo täytettiin lähes täyteen $0.1 \mathrm{~N}$ suolahapolla, johon oli lisätty $0.1 \%$ pepsiiniä (Merck 1: 3500 ), suljettiin tulpalla ja pidettiin alussa tunnin välein ravistaen $20 \mathrm{t}$ kuivauskaapissa $40^{\circ}$ C:ssä. Seos suodatettiin proteiinimäärityksessä suodatinpaperin ja jäännöksen määrityksessä Gooch-lasivilla upokkaan läpi sekä pestiin vedellä. Jäännöksestä määritettiin raakaproteiini tai hehkutuskevennys ja erotuksena saatiin liuenneet määrät. In vitro -sulavuus määritettiin TILleyn ja TERRYn (1963) menetelmällä, kationit A-1000 Techtron atomiabsoptiospektrofotometrillä ja fosfori TAYsSKYn ja SHORRin (1953) menetelmällä.

\section{Tulokset ja tarkastelu}

\section{Kehityksen kulku vuonna 1973}

Vuonna 1973 kevät oli hyvin suotuisa (taulukko 1), nurmikasvit olivat talvehtineet hyvin ja nurminadan ja timotein kasvu alkoi varhain ja edistyi touko-kesäkuun vaihteessa nopeasti (kuvat 1 ja 2 ). Kasvun ollessa voimakkainta raakaproteiinipitoisuus laski yli $1 \%$-yksikköä ja pepsiini- HCl-liukoinen 


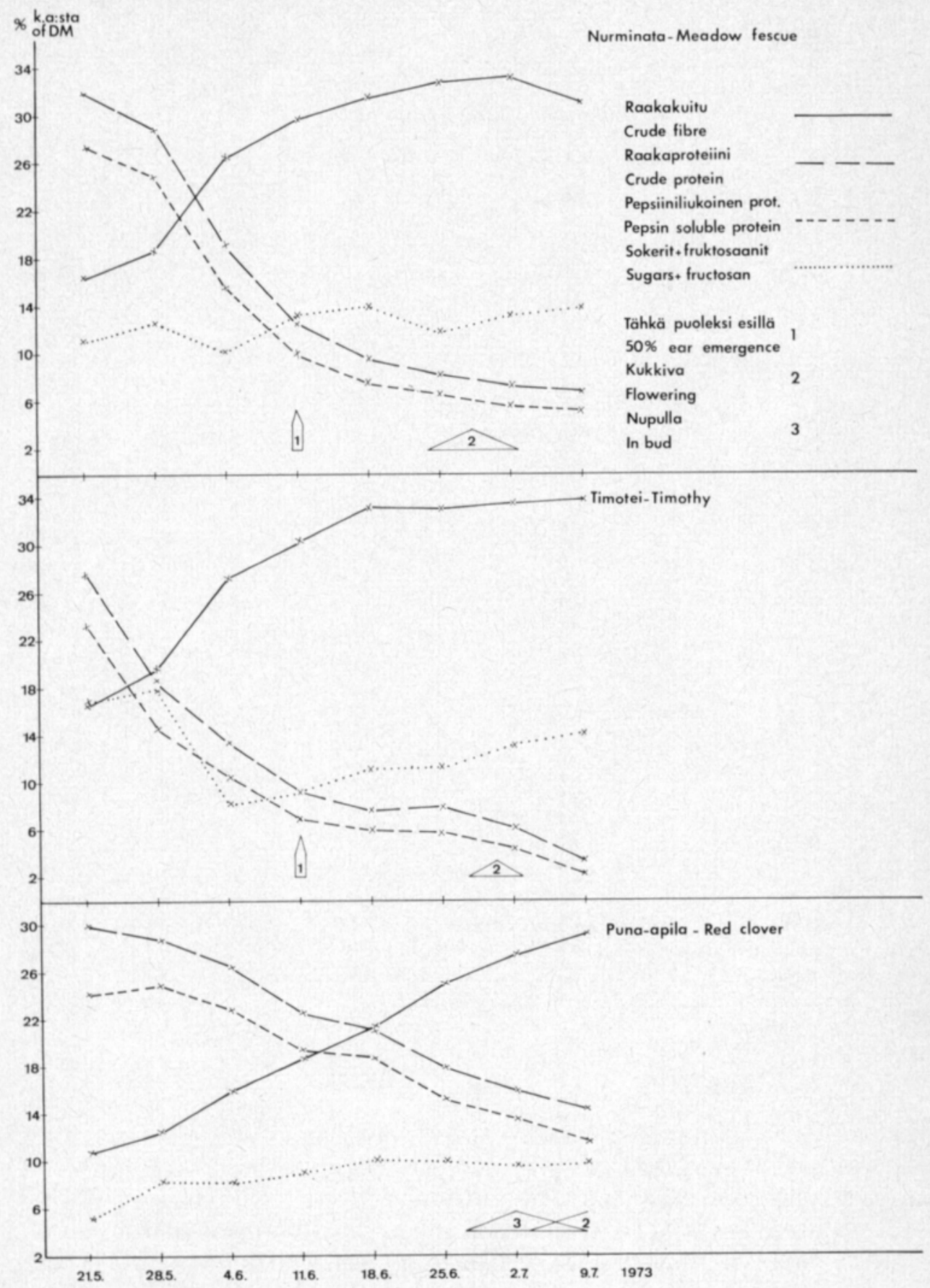

Kuva 1. Kasvuasteen vaikutus nurminadan, timotein ja puna-apilan koostumukseen.

Figure 1. Effect of the growth stage on the composition of meadow fescue, timothy and red clover. 


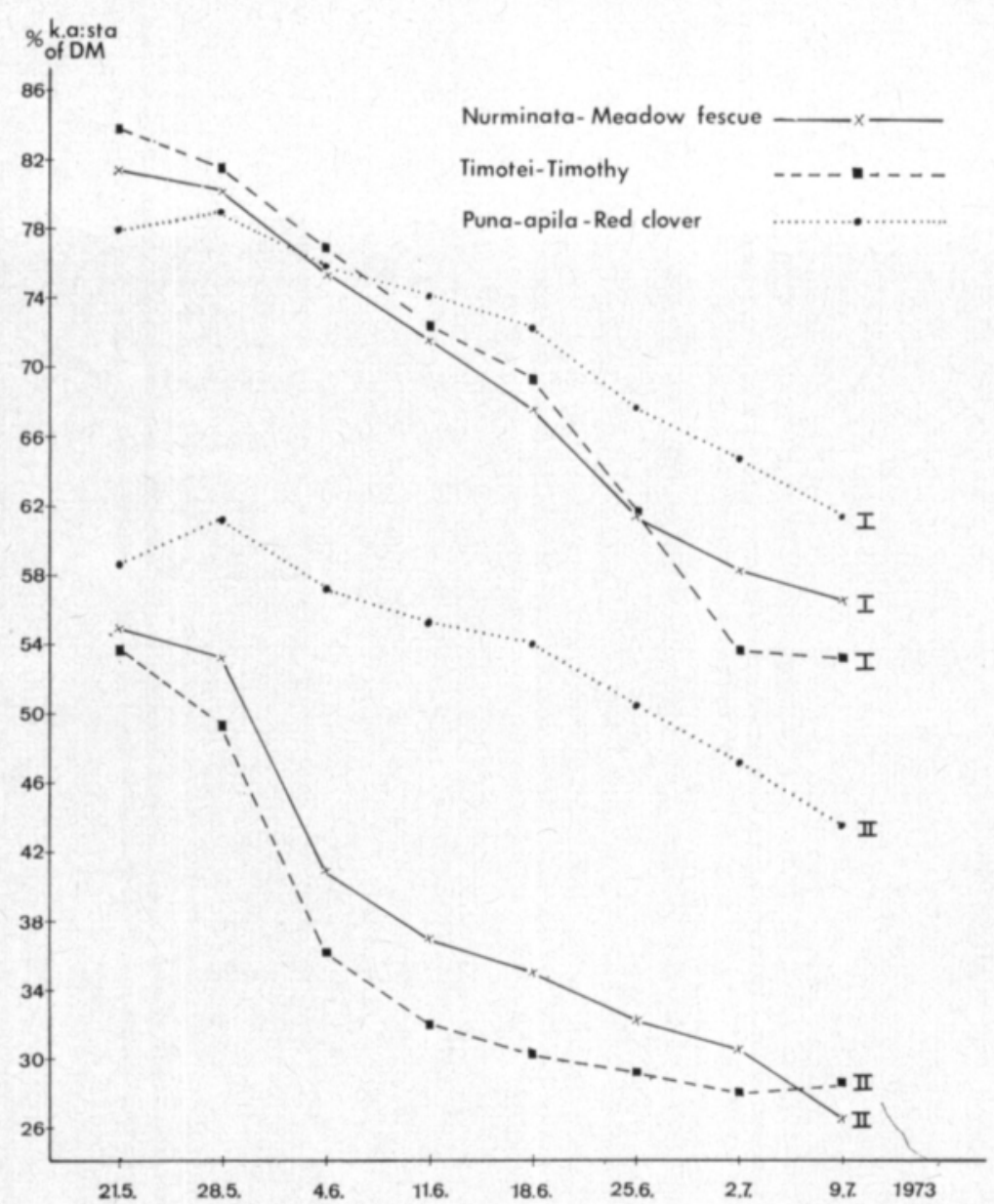

Kuva 2. Kasvuasteen vaikutus orgaanisen aineen in vitro -sulavuuteen (I) ja pepsiini-HCl- liukoisuuteen (II).

Figure 2. Effect of the growth stage on the in vitro digestibility (I) and the pepsin- $\mathrm{HCl}$ solubility (II) of organic matter.

orgaaninen aine lähes $2 \%$-yksikköä vuorokaudessa (taulukko 3 ). Raakakuitupitoisuus nousi vastaavasti ja saavutti lähes maksimitason noin $1 \frac{1}{2}$ viikkoa ennen heinäkasvien kukintaa. In vitro-sulavuuden lasku oli suhteellisen loivaa ja suoraviivaista ja jatkui senkin jälkeen kun kuitupitoisuuden nousu oli pysähtynyt. (Ligniini- ja ksylaanipitoisuus nousee jatkuvasti ja alentaa sulavuutta, mutta ei juuri nosta kuitupitoisuutta). Vesiliukoisten hiilihydraattien pitoisuus oli nopean kasvun vuoksi kaiken aikaa suhteellisen matala. Pepsiiniliukoista raakaproteiinia oli lehtiasteella noin $4 \%$-yksikköä vähemmän kuin raakaproteiinia.

Puna-apilan kehitys poikkesi paljon heinäkasvien kehityksestä (kuvat 1 ja 2, taulukko 3). Nuppujen muodostuminen alkoi noin neljä viikkoa myöhemmin kuin heinäkasvien tulo tähkä- ja röyhyasteelle. Koostumus muuttui vastaavasti hitaammin ja muutokset olivat varsin suoraviivaisia. 
Taulukko 3. Koostumuksen muuttuminen keskimäärin vuorokautta kohti, \%-yksikköä. Table 3. The average changing of composition per day, $\%$-units.

\begin{tabular}{|c|c|c|c|c|c|c|c|c|c|}
\hline \multirow[b]{2}{*}{1973} & \multicolumn{3}{|c|}{$\begin{array}{l}\text { Raakaproteiini } \\
\text { Crude protein }\end{array}$} & \multicolumn{3}{|c|}{$\begin{array}{c}\text { Pepsin-HCl-liuk. }{ }^{1} \text { ) } \\
\text {, solub. }\end{array}$} & \multicolumn{3}{|c|}{$\begin{array}{l}\text { Raakakuitu } \\
\text { Crude fibre }\end{array}$} \\
\hline & $\mathrm{N}$ & $\mathrm{T}$ & A & $\mathrm{N}$ & $\mathrm{T}$ & A & $\mathrm{N}$ & $\mathrm{T}$ & A \\
\hline $21 .-28.5, \ldots \ldots \ldots \ldots \ldots \ldots \ldots \ldots$ & 0.44 & 1.33 & 0.15 & 0.23 & 0.63 & +0.34 & 0.32 & 0.43 & 0.21 \\
\hline $28.5 .-4.6 . \ldots \ldots \cdots \cdots \cdots \cdots \cdots \cdot \ldots$ & 1.41 & 0.74 & 0.33 & 1.77 & 1.89 & 0.56 & 1.13 & 1.11 & 0.51 \\
\hline 4. $-11.6 . \quad \ldots \ldots \ldots \ldots \ldots \ldots \ldots$ & 0.91 & 0.59 & 0.56 & 0.57 & 0.59 & 0.27 & 0.44 & 0.42 & 0.41 \\
\hline 1974 & $\mathrm{~N}$ & $\mathbf{T}$ & $\mathrm{J}$ & $\mathrm{N}$ & $\mathrm{T}$ & $\mathrm{J}$ & $\mathrm{N}$ & $\mathbf{T}$ & $\mathrm{J}$ \\
\hline 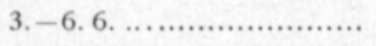 & 2.13 & 1.30 & - & 0.43 & 0.73 & - & 0.60 & 0.43 & - \\
\hline 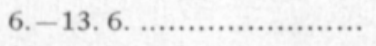 & 0.53 & 0.41 & - & 1.67 & 1.84 & - & 0.84 & 0.90 & - \\
\hline $13 .-2.6 \quad \ldots \ldots \ldots+\cdots \cdots \cdots \cdots$ & 0.80 & 0.47 & 0.81 & 0.97 & 1.34 & 0.86 & 0.66 & 0.89 & 0.69 \\
\hline
\end{tabular}

1) Pepsiini-HCl-liukoinen orgaaninen aine - Pepsin- $\mathrm{HCl}$ soluble organic matter.

Taulukko 4. Nurminadan (N), timotein (T) ja juolavehnän (J) koostumus 1974, \% k.a:sta. Table 4. Composition of meadow fescue (N), timothy (T) and couch-grass (J) 1974, \% of dry matter.

\begin{tabular}{|c|c|c|c|c|c|c|c|c|}
\hline \multirow{2}{*}{$\begin{array}{l}\text { Aika } \\
\text { Date }\end{array}$} & \multirow{2}{*}{$\begin{array}{l}\text { Kasvi } \\
\text { Plant }\end{array}$} & \multirow{2}{*}{$\begin{array}{l}\text { Raakaproteiini } \\
\text { Grude protein }\end{array}$} & \multicolumn{2}{|c|}{$\begin{array}{c}\text { Pepsiini-HCl-liukoinen } \\
\text { Pepsin- } \mathrm{HCl} \text { soluble }\end{array}$} & \multirow{2}{*}{$\begin{array}{c}\text { Sokerit }+ \\
\text { frukto- } \\
\text { saanit } \\
\text { Sugars + } \\
\text { fructosan }\end{array}$} & \multirow{2}{*}{$\begin{array}{l}\text { Raaka- } \\
\text { kuitu } \\
\text { Crude } \\
\text { fibre }\end{array}$} & \multirow{2}{*}{$\begin{array}{l}\text { Tuhka } \\
\text { Ash }\end{array}$} & \multirow{2}{*}{$\begin{array}{c}\text { In vitro } \\
\text {-sulavaa } \\
\text { - soluble } \\
\text { org. } \\
\text { matter }\end{array}$} \\
\hline & & & $\begin{array}{l}\text { Crude } \\
\text { protein }\end{array}$ & $\begin{array}{l}\text { Organic } \\
\text { matter }\end{array}$ & & & & \\
\hline \multirow[t]{2}{*}{ 3. 6.} & $\mathbf{N}$ & 29.8 & 26.4 & 57.7 & 15.9 & 16.0 & 9.8 & 83.5 \\
\hline & $\mathrm{T}$ & 20.8 & 18.0 & 55.8 & 23.6 & 17.2 & 7.6 & 86.9 \\
\hline \multirow[t]{2}{*}{ 6. 6.} & $\mathrm{~N}$ & 23.4 & 19.9 & 56.4 & 22.2 & 17.8 & 8.1 & 83.0 \\
\hline & $\mathbf{T}$ & 16.9 & 14.4 & 53.6 & 26.4 & 18.5 & 6.3 & 82.5 \\
\hline \multirow[t]{3}{*}{ 13. 6.} & $\mathrm{~N}$ & 19.7 & 17.2 & 44.7 & 12.4 & 23.7 & 9.6 & 81.3 \\
\hline & $T$ & 14.0 & 11.6 & 40.7 & 14.5 & 24.8 & 7.0 & 76.7 \\
\hline & $\mathbf{J}$ & 24.0 & 20.5 & 46.0 & 9.8 & 22.1 & 8.4 & 79.6 \\
\hline \multirow[t]{3}{*}{ 17. 6.} & $\mathrm{~N}$ & 15.3 & 12.7 & 40.7 & 12.4 & 27.6 & 9.1 & 75.7 \\
\hline & $T$ & 13.1 & 10.8 & 37.0 & 11.8 & 28.6 & 7.1 & 74.5 \\
\hline & $\mathrm{J}$ & 21.1 & 17.7 & 43.7 & 9.7 & 24.1 & 10.0 & 76.1 \\
\hline \multirow[t]{3}{*}{20.6 . } & $\mathrm{N}$ & 14.1 & 11.8 & 37.9 & 11.2 & 28.3 & 8.8 & 73.4 \\
\hline & $T$ & 10.7 & 8.8 & 31.3 & 9.2 & 31.0 & 6.6 & 70.7 \\
\hline & $\mathbf{J}$ & 18.3 & 15.5 & 40.0 & 9.6 & 26.9 & 9.2 & 72.6 \\
\hline
\end{tabular}

\section{Vertailu vuoteen 1974 ja kirjallisuuteen}

Kevät 1974 oli vuorostaan epäedullinen, huhtikuu vähäsateinen ja toukokuu sekä kesäkuun alku kolea (taulukko 1). Kasvit olivat lisäksi talvehtineet huonosti. Kasvu alkoi suunnilleen kaksi viikkoa myöhemmin kuin vuonna 1973. Ruohojen koostumus nähdään taulukosta 4 . 


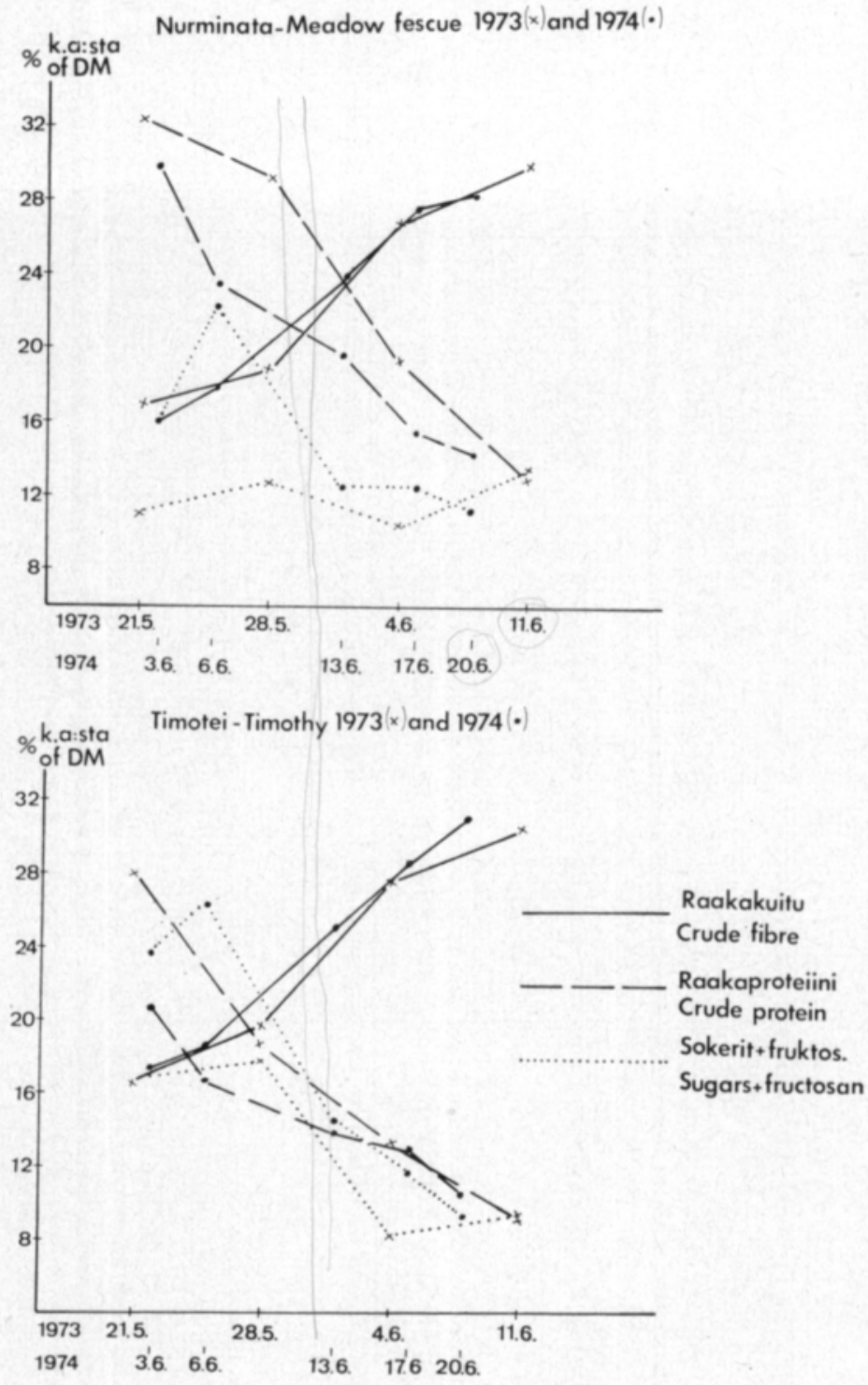

Kuva 3. Ruohon koostumus suotuisana (1973) ja epäsuotuisana (1974) keväänä.

Figure 3. Composition of grasses in the favourable (1973) and unfavourable (1974) spring.

Kuvassa 3 on vuosien 1973 ja 1974 näytteet pyritty asettamaan kasvuasteen mukaisesti samalle kohdalle. Silmiinpistävimpänä erona huomataan, että kolean kevään (1974) ruohon proteiinipitoisuus oli lehtiasteella 6-8\%yksikköä suotuisan kevään pitoisuutta alempi ja sokeripitoisuus saman verran korkeampi. Tulos pitää yhtä GröBelin ja STEEnin (1964) havainnon kanssa että ruohon hidas kasvu johtaa matalaan proteinipitoisuuteen. Vuonna 1973 heinäkasvien proteiinipitoisuudet lehtiasteella olivat toisaalta poikkeavan 
korkeita verrattuna Norjasta (Номв 1953), Ruotsista (KIVImäE 1959, 1965) ja Suomesta (Poutiarnen ja Rinne 1970) aiemmin julkaistuihin tuloksiin. Pepsiini-HCl-liukoisuudessa ei lehtiasteisessa ruohossa vuosien välillä ilmennyt eroa, mikä oli odotettavissakin koska proteiinin ja vesiliukoisten hiilihydraattien summa oli sama. Ei liioin in vitro -sulavuudessa ollut eroa. Tuhkapitoisuus oli vuonna 1974 noin $2 \%$-yksikköä vuoden 1973 pitoisuutta alempi.

Koe osoitti eroja myös heinäkasvilajien välillä. Timotei lähti kasvuun nurminataa nopeammin ja sen koostumus huononi lehtiasteella nataa nopeammin, vaikka kukinnon esiintulo tupesta tapahtui molemmilla samanaikaisesti. Ero näkyi sekä raakaproteiinipitoisuudessa että pepsiini-HCl-liukoisuudessa. (Timotein alemmalla typpilannoituksella $-40 \mathrm{~kg} / 75 \mathrm{~kg} \mathrm{~N} / \mathrm{ha}-$ saattoi olla osuutta eroon.) Natalohkolta vuonna 1974 tutkittu juolavehnä osoittautui lehtiasteisena koostumukseltaan timoteitä ja nataa paremmaksi (taulukko 4). Se oli näitä lehtevämpi (taulukko 2) ja tähkän esiintulo alkoi noin 9 päivää myöhemmin kuin nadalla ja timoteillä. Huonosti talvehtineessa nurmessa se lähti keväällä nataa nopeammin kasvuun, mutta jäi tiheässä kasvustossa myöhemmin alakynteen. Ensimmäisen niiton jälkeen se jälleen kasvuunlähdössä voitti nadan. Väheksytty juolavehnä näyttää siten olevan huonosti talvehtivissa nurmissa arvokas täydennyskasvi.

Tutkimuksessa ei määritetty ha-satoja, mutta suurin piirtein satomäärät saadaan selville vuonna 1973 nurminadasta ja vuonna 1974 timoteistä SYRJ ÄLÄn (1973) samoilta lohkoilta tekemistä säilörehukokeista. Niinpä natasato oli vuonna 1973 suositeltavana viherjauhon niittoaikana eli 28. 5. noin $1700 \mathrm{~kg}$ k.a./ha ja määrä nousi seuraavan viikon aikana noin 1.5 kertaiseksi. Vuonna 1974 timoteisato oli 6.6. $1660 \mathrm{~kg} \mathrm{k}$.a./ha ja määrä nousi viikossa noin 1.3kertaiseksi. Edullisinta niittoaikaa seuraava kasvu ei kuitenkaan aina ole näin nopeata, esim. Poutiaisen ja Rinteen kokeessa vuonna 1970 se oli paljon hitaampaa.

\section{Kivennäiskoostumus}

Vuonna 1973 näytteistä määritettiin myös kivennäispitoisuudet ja todettiin seuraavaa (kuva 4): Voimakkaimman kasvuvaiheen aikana nurmikasvien K-, Fe-, Mn- ja Zn-pitoisuudet laskivat jyrkästi ja P-sekä Ca-pitoisuudet loivasti. Mg- ja C-pitoisuudet olivat varsin tasaiset koko kasvukauden. Sateen aiheuttama lakoutuminen sai nadassa aikaan korkeita Fe-arvoja (multakontaminaatio). Natriumia kasveissa oli hyvin vähän $(0.1-0.2 \mathrm{~g} / \mathrm{kg}$ k.a.) eikä kehitysastevaihtelua tai eroa kasvilajien välillä ilmennyt. Tuhkapitoisuus oli vuonna 1973 selvästi korkeampi kuin vuonna 1974. 


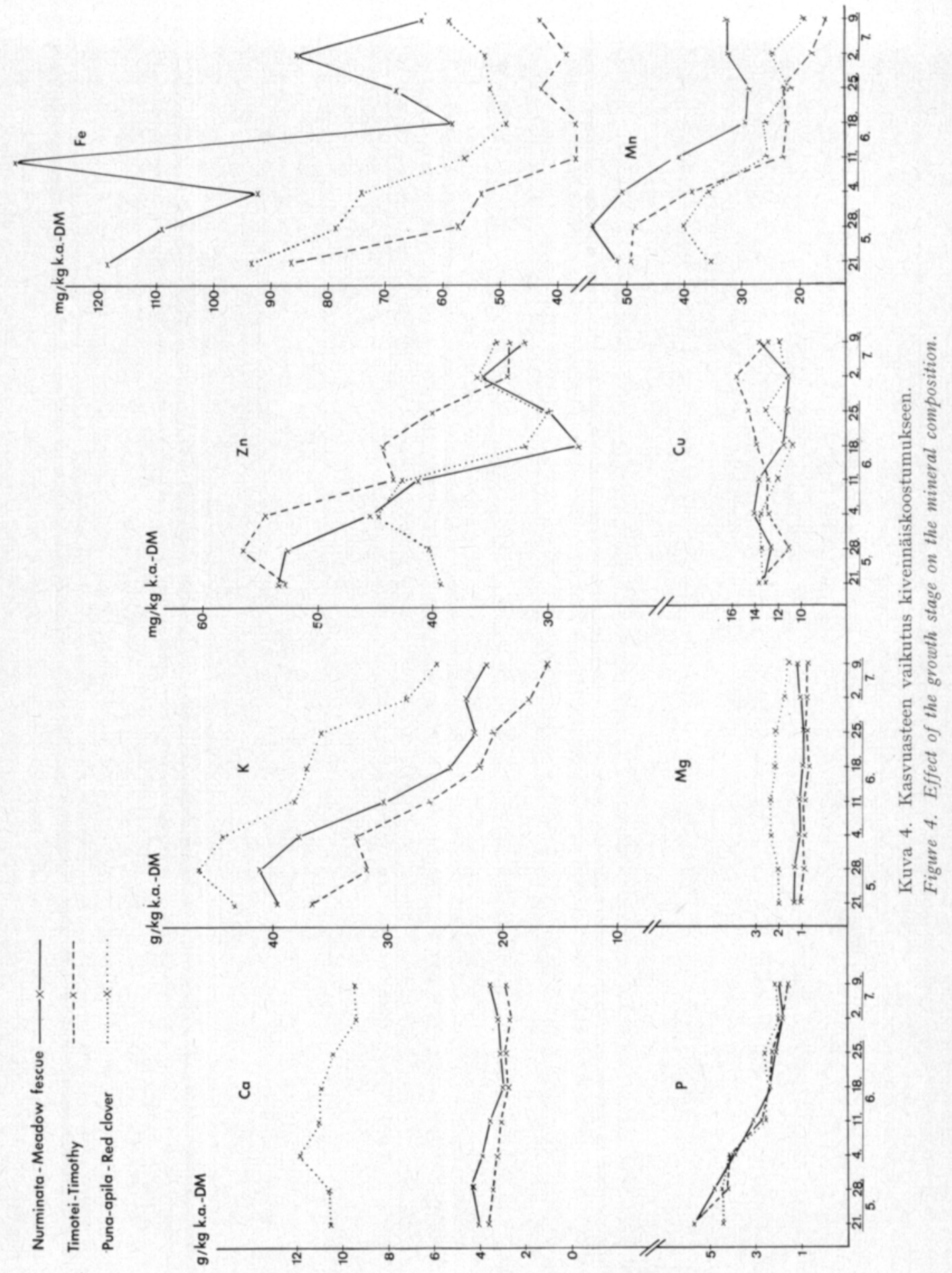




\section{Johtopäätökset}

Nurminadan ja timotein ensimmäinen sato pitäisi korjata viherjauhoksi silloin kun kasvusto on $25-35 \mathrm{~cm}$ :n korkuista, timotei $2-3$ päivää ennen nataa. Kasvit ovat silloin 2-3 lehtiasteella ja kukintojen esiintuloon on aikaa $1^{1} / 2-2$ viikkoa. Suotuisana keväänä ruoho sisältää tällöin raakaproteiinia noin $24-28 \%$ ja huonona keväänä $16-21 \%$ kuiva-aineesta. Proteiinin sulavuus yksimahaisillakin on hyvä, sillä sen pepsiiniliukoisuus on $80-85 \%$. Pepsiiniliukoista orgaanista ainetta on $50 \%$ tai vähän yli, mikä merkitsee että sulavuus myös yksimahaisilla on suhteellisen hyvä. In vitro -sulavaa orgaanista ainetta on $80-82 \%$ kuiva-aineesta. Kuitupitoisuus on alle $20 \%$. Tällaisella viherjauholla on jo merkitystä sikojen ja siipikarjan rehuseosten valkuais- ja aminohappopitoisuuden korjaajana; se sisältää runsaasti valkuaista ja sitä voidaan hyvän sulavuuden ansiosta lisätä seokseen tavallista enemmän.

Korjattaessa ruohoa märehtijäin rehuksi ei sulavuuteen tarvitse kiinnittää samassa määrin huomiota, koska ruohon sulavuus märehtijöillä in vitro -tuloksista päätellen alenee hitaasti. Valkuaispitoisuuden jyrkkä huononeminen on kuitenkin säilörehun teossakin syytä ottaa huomioon. On myös todettu, että ruohon maittavuus korreloituu pepsiini-HCl-liukoisuuteen paljon kiinteämmin kuin in vitro-sulavuuteen (DONEFER ym. 1963, 1966), joten runsasta säilörehun käyttöä tavoiteltaessa aikainen korjuu on eduksi.

Puna-apila on heinäkasveja edullisempi viherjauhokasvi, koska raakaproteinipitoisuus ja pepsiini-HCl-liukoisuus laskee hitaasti. Triploidi punaapila oli vielä kolmisen viikkoa myöhemmin samanveroista kuin nurminata suositeltuna korjuuaikana. Apilan viljely tasoittaa siten viherjauhotehtaiden työhuippua alkukesällä. Haittapuolena on huonon talvenkestävyyden lisäksi korkea vesipitoisuus, mikä nostaa kuivatuskustannusta. Huomattakoon kuitenkin, että heinäkasveista saa lähes apilan veroista viherjauhoa, mutta korjuu täytyy suorittaa varhaisella kasvuasteella ja aivan muutaman päivän aikana.

Heinäkasveista nurminata on laadullisesti timoteita parempi viherjauhokasvi, koska se samalla kasvuasteella sisältää enemmän raakaproteiinia ja pepsiini-HCl-liukoista ainetta ja kyseiset pitoisuudet alenevat hitaammin. Juolavehnä osoittautui rehuarvon kannalta tarkasteltuna nurmissa edulliseksi rikkakasviksi, sillä se tulee tähkälle noin 9 päivää myöhemmin kuin nurminata ja timotei ja on sen vuoksi lehtiasteella näitä lehtevämpi ja proteiinirikkaampi. 


\section{KIRJALLISUUS}

Donefer, E., Niemann, P. J., Crampton, E. W. \& Lloyd, L. E. 1963. Dry matter disappearance by enzyme and aqueous solutions to predict the nutritive value of forages. J. Dairy Sci. 46: $965-970$.

- - , Crampton, E. W. \& Lloyd, L. E. 1966. The prediction of digestible energy intake potential (NVI) of forages using a simple in vitro techniques. Proc. X. Internat. Grassl. Congr. $442-445$.

Fulkerson, R. S., Mowat, D. N., Tossell, W. E. \& Winch, J. E. 1967. Yield of dry matter, in vitro digestible dry matter and crude protein of forages. Canad. J. Plant Sci. 47: $683-690$.

GlöBel, G. \& SteEn, E. 1964. Betets kemiska säsongvariation - resultat av tre fältförsök. Lantbr. högsk. Medd. Serie A. Nr. 21, 45 p.

Номв, T. 1953. Chemical composition and digestibility of grassland crops. Acta Agric. Scand. 3: $1-32$.

KıvimÄe, A. 1959. Chemical composition and digestibility of some grassland crops. Acta Agric. Scand. Suppl. 5:1-412.

- - 1965. Timotejhöets sammansättning och smältbarhet vid framskridande skördestadier. Lantbr. högsk. Medd. 37:1-23.

Poutıainen, E. \& Rinne, K. 1971. Korjuuasteen vaikutus säilörehun ravintoarvoon. Kehittyvä maatalous $3: 15-28$.

SaLo, M.-L. 1965. Determination of carbohydrate fractions in animal foods and faeces. Acta Agr. Fenn. 105: 1-102.

SyrJäLÄ, L. 1973. Mennyt kesä ja vihreä linja. Karjatalous 10/1973:42-43.

TAUSSKY, H. H. \& SHORR, E. 1953. A microcolorimetric method for the determination of inorganic phosphorus. J Biol. Chem. 202: 675-685.

Tilley, J. M. \& Terry, R. A. 1963. A two-stage technique for the in vitro digestion of forage crops. J. Brit. Grassl. Soc. 18: 104-111. 